The Egyptian Journal of Hospital Medicine Vol., 13 : 75 - 89

Dec 2003

I.S.S.N: 12084

1687-2002

\title{
Quantitative microscopical and histochemical changes in the Liver and Testis of adult rabbit under the effect of oral intake of cotton seeds Gossypol
}

\author{
Hassan S. El-Dawi, Ahmed N. Al-Kasaby, Bassem S. Ahmed* \\ and Amir M. Al-Nagar* \\ Histology Department, Faculty of Medicine Al-Azhar University Cairo and Assuit*
}

\begin{abstract}
Gossypol is a natural yellowish phenolic compound (dimeric or bis-naphthalene) isolated from the seeds of cotton plants (Gossypium species).

The aim of the present work was to study the possible microscopical and histochemical changes in the liver and testis of adult rabbit under the effect of oral intake of cotton seeds Gossypol.

Eighteen 6month age adult male rabbits were subdivided into 3 equal groups (control, experimental and recovery). The experimental and recovery groups were subjected to $1.05 \mathrm{mg} / \mathrm{day}$ Gossypol suspended in olive oil intubation for 9 weeks and the recovery rabbits were left 9 weeks after last dose.

Liver and testis paraffin sections were processed and stained with Hematoxylin and eosin stain for morphological changes. Glycosaminoglycans in the seminiferous tubules were stained by PAS technique. Studying of the nucleic DNA in the spermatogenic cells was done by Feulgen technique. Quantitative study included seminiferous tubules thickness; spermatogonia and primary spermatocytes cell areas. Also the distribution of PAS positive materials analyzed as area percent and nucleic DNA as optical density. All analysis was done by the aid of image analysis System.

The study showed that liver was affected by gossypol administration. The changes appeared as distinct pinpoint foci of coagulative necrosis, vacuolar degeneration of hepatocytes and dilation of the sinusoids with mild perivascular lymphoid aggregation.

The testis showed distortion loss of spermatogenic cells, Sertoli and germ organization under the effect of gossypol. Sertoli cells showed an intracellular vacuolization. Also, there were luminal multinucleated giant cells as well as a prominent DNA fragmentation in the spermatogonia nuclei. The quantitative study showed statistically significant decrease in the mean thickness of seminiferous tubules, the mean area of spermatogonia, and primary spermatocyte, mean area percent of distribution of PAS positive materials of seminiferous tubules and a significant increase in the mean optical density of nucleic DNA of spermatogonia affinity to Feulgen stain in experimental group, $(\mathrm{p}<0.001)$. After 9 weeks recovery periods most of the morphological and quantitative changes were still present.

The study concluded that gossypol has a toxic effect on the liver and testis of rabbits and their toxicity may be more prominent in humans.

The study recommend restriction of uses of cotton seed oil in human uses and further study on the possible risk of uses of cattle fed on cottonseed meals.
\end{abstract}




\section{Quantitative microscopical and histochemical changes}

\section{Introduction}

Gossypol is a dimeric or bisnaphthalene extracted from some species of cotton seeds. It is present in the level of $0.8 \%$ of whole cotton seed to protect it from insect damage.

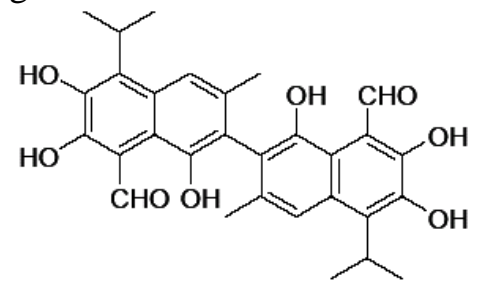

In the 1970's, the Chinese government began large-scale research on the possible use of gossypol as a non-hormonal fertilityinhibiting agent (male contraceptive). These studies involved over 10,000 subjects, and continued for over a decade. (Morris 1986).

The researchers found that gossypol provided reliable contraception, could be taken orally as a tablet, and did not upset men's balance of hormones. (Qian, and Wang, 1984).

In 1986, the Chinese research program was called to a halt due to concerns about developing azoospermic after prolonged use of gossypol and about 5 and 25 percent of the men remained infertile up to a year after stopping treatment.

The failure of recovery was strongly associated with longer treatment, greater total dose of gossypol, smaller testicular volume, elevated FSH [follicle stimulating hormone] concentrations and, to a lesser extent, with greater body weight (Meng et al., 1988).

Also about $10 \%$ among subjects had an abnormally high rate of hypokalemia as the result of kidney malfunction, although exactly how gossypol affects renal function is unknown (Waites 1993).

Researchers in Brazil have undertaken trials of low dose gossypol and, a Brazilian pharmaceutical company Hebron announced plans to market a low dose gossypol pill called Nofertil, but the pill never came to market and indefinitely postponed due to unacceptably high rates of infertility.

In 1998, the World Health Organization's Research Group on Methods for the Regulation of Male Fertility reviewed the research on gossypol and concluded that contraceptive research should be abandoned (Waites et al 1998).

In addition to the side effects mentioned above, the WHO researchers have major concerns about gossypol's toxicity. The toxic dose in primates is less than 10 times the contraceptive dose. This report will effectively halt further research into this method in the developed world (Waites et al 1998).

Because Cotton implantation is the main plant agriculture in Egypt and production of cotton has increased in the last few years. The economic utilization of cottonseed product for human nutrition is also. Cottonseed oil is used in food preparation and cooking as salad oil, shortening, and margarine.

Also the human use of crude cottonseed oil has also increased rapidly as cosmetic ingredients such as skin-conditioning agents and surfactants which containing cottonseed oil or derivatives (hydrogenated oil, cottonseed acid, cottonseed glyceride, and hydrogennated cottonseed glyceride. (Int Toxicol. 2001).

Also the whole cottonseeds are consumed by beef cattle producers although the Cattle have the ability to detoxify gossypol because the microorganisms in the rumen bind it so it can't be absorbed.

\section{Materials and Methods}

\section{Materials:}

\section{A-The Drug}

The pure gossypol was obtained as a $250 \mathrm{mg}$ vial from Sigma Chemical Corp. (Lot. 80K 4082). The powder is water insoluble but 
soluble in ethanol or ether. It is stable at 2-8 ${ }^{0} \mathrm{C}$. The dose was calculated according to the human therapeutic dose after Paget's modification for rabbits.

The gossypol powder was suspended in pure olive oil as a vehicle and was shaking well before use and was given orally by gastric tube.

\section{B-The Animal}

Eighteen, 6months age, healthy adult male rabbits with average weight $1.5 \mathrm{Kg}$ were subjected to the study.

The rabbits were subdivided into 3 equal groups; Control, Experimental and Recovery.

Control group rabbits were the healthy rabbits intubated orally with $1 \mathrm{ml}$ olive oil daily for 9 weeks.

Experimental group represented rabbits intubated with $1.05 \mathrm{mg}$ gossypol suspended in $1 \mathrm{ml}$ olive oil daily for 9 weeks.

Recovery group represented rabbits treated with same protocol as experimental followed by 9 weeks recovery period after the last gossypol dose.

\section{The Methods:}

The rabbits of control and experimental groups were sacrificed after $24 \mathrm{hrs}$ after last intubation, while those of recovery were sacrificed at the end of recovery period.

The testis and liver were dissected and fixed in neutral buffered formol and processed for preparation of 5um paraffin section slides.

Morphometric study on the liver was done on sections stained by Hematoxylin and Eosin stain.

The paraffin testicular sections slides were stained by Hematoxylin and Eosin stain for morphological study. Demonstration of DNA contents in spermatogenic cells was done by Feulgen technique. Periodic Acid Schiff (PAS) technique was applied for detection of glycosaminoglycans of testicular tissue (Drury and Wallington, 1996).
Quantitative morphometric studies were done on the testis by the aid of SuperEye Image Analyzer System - HeidiSoft Corporation - Egypt.

The quantitative studies were done on twenty field for each rabbit and included thickness of seminiferous tubules (heights of spermatogenic cells), cell areas of spermatogonia and primary spermatocytes.

Distribution of PAS positive materials in seminiferous tubules was evaluated as area percent (relative to area of seminiferous tubule)

Nuclear DNA affinity to Feulgen stain in the spermatogonia cells was analyzed as an optical density.

The obtained data were statistically analyzed using student t-Test for comparison between experimental, recovery and control values.

\section{Results:}

\section{Liver:}

The normal histological appearance of control group was shown in Plate 1-A

Gossypol administration caused distinct pinpoint foci of hepatocytes with degenerative changes and coagulative necrosis. Plate 1-B

A marked vacuolar degeneration of hepatocytes and dilation of the sinusoids in the liver was observed. Plate 1-C. Also there was mild perivascular lymphoid aggregation and increased intravascular blood leucocytes. Plate 1-D and 1-E

In recovery groups the hepatocytes intracellular vacuolization were still present but lesser than in experimental rabbits. Plate $1-\mathrm{F}$

\section{Testis:}

\section{Morphological Results}

Plate 2-A is showing the normal pattern of seminiferous tubules of control rabbits and the organization of testicular cells and the intimate relationships between Sertoli and germ cells.

In Experimental group, the testis showed perturbing the adhesion of germ cells 


\section{Quantitative microscopical and histochemical changes}

onto the Sertoli cell (Plate 2-B). Presence of degenerated seminiferous tubules (Plate-2-C), which formed of one row of spermatogonia cells. The Sertoli cells showed an intracellular vacuolization. (Plate-2-D). Some multinucleated giant cells were present in the lumen of some seminiferous tubules (Plate-2-E). A prominent cellular internucleosomal DNA fragmentation was observed in the spermatogenic cells (Plate-2-F)

Presence of blood leucocytes inbetween spermatogenic cells (Plate-2-G).

In Recovery group, the seminiferous tubules showed residual bodies, absence of luminal sperms. Plate 2-H

\section{Histochemical Results}

\section{Periodic Acid Schiff}

The control seminiferous tubules showed PAS positive reaction in the spermatogenic cells and more prominent in head of sperms (Plate 3-A).

The experimental seminiferous tubules showed a decrease in the PAS positive materials (Plate 3-B).

Weak PAS positive materials were noticed in the seminiferous tubules of recovery group testis in comparison to that of control group (Plate 3-C).

\section{Feulgen Technique for Nucleic DNA}

The affinity of nucleic DNA molecules to Feulgen stain in the control spermatogenic cells was shown in Plate3-D.

In experimental and recovery groups seminiferous tubules showed an increase affinity to Feulgen stain in spermatogenic cells in comparison to control the control (Plate 3-E and 3-F respectively).

Quantitative Morphological Results(Table 1) Thickness of seminiferous tubules epithelium (Spermatogenic cells height):

The mean thickness in the control group was 70.126um, SD 13.616 and SEM 2.723. In experimental testis the mean thickness was 39.282um, SD 9.057 and SEM 1.811

The mean thickness in the recovery group was 48.576um, SD 11.202 and SEM 2.040.
The student t-test showed, statistically significant decrease in the mean thickness of seminiferous tubules in experimental and recovery groups in comparisons to control values $(p<0.001)$ (Figure-1).

\section{Spermatogonia cell area:}

The mean area of spermatogonia of the control group was $76.407 \mathrm{um}^{2}$, SD 17.017 and SEM 3.403.

In experimental testis the mean area was 26.617 $\mathrm{um}^{2}$, SD 4.650 and SEM 0.930

The mean area in the recovery group was 32.926um ${ }^{2}$, SD 7.464 and SEM 1.627.

The student t-test showed statistically significant decrease in the mean area of spermatogonia in experimental and recovery groups in comparisons to control values ( $\mathrm{p}<$ 0.001) (Figure-2).

\section{Primary Spermatocyte cell area:}

The mean area of primary spermatocyte of the control group was $143.730 \mathrm{um}^{2}$, SD 27.619 and SEM 5.524.

In experimental testis the mean area was 29.302 $\mathrm{um}^{2}$, SD 7.728 and SEM 1.546

The mean area in the recovery group was $68.828 \mathrm{um}^{2}$, SD 9.776 and SEM 1.955.

The student t-test showed, statistically significant decrease in the mean area of primary spermatocyte in experimental and recovery groups in comparisons to control values $(\mathrm{p}<0.001)$ (Figure-2).

Quantitative Histochemical Results(Table 1) Distribution of PAS positive materials in seminiferous tubules (\%):

The mean area percent of PAS positive materials in the seminiferous tubules of control rabbits was 13.023, SD 1.956 and SEM 0.437.

In experimental seminiferous tubules, the mean area percent was 8.537 , SD 1.705 and SEM 0.381.

In the recovery group, the mean area percent was 4.97, SD 1.179 and SEM 0.264. The student t-test showed, statistically significant decrease in the mean area percent 
of distribution of PAS positive materials of seminiferous tubules in experimental and recovery groups in comparisons to control values $(\mathrm{p}<0.001)$ (Figure-3).

Optical density of nucleic DNA in spermatogonia cells:

The mean optical density of DNA in spermatogonia of control group rabbits was 0.285 SD 0.057 and SEM 0.013
In experimental group the mean was 0.424, SD 0.082 and SEM 0.018

The mean area in the recovery group was 0.377, SD 0.074 and SEM 0.016.

The student t-test showed statistically significant increase in the mean optical density of nucleic DNA of spermatogonia affinity to Feulgen stain in experimental and recovery groups in comparisons to control values $(\mathrm{p}<0.001)$ (Figure-4).

Table -1 Effect of gossypol oral intake on the seminiferous tubules thickness, spermatogonia and primary spermatocytes cells areas, PAS positive area percent and spermatogonia DNA optical density in the different study groups

\begin{tabular}{|c|c|c|c|c|c|c|}
\hline & Mean & SD & SEM & t-Test & p-value & Significance \\
\hline \multicolumn{7}{|c|}{ Seminiferous tubules thickness (ųm) } \\
\hline Control & 70.126 & 13.616 & 2.723 & & & \\
\hline Experim. & 39.282 & 9.057 & 1.811 & $1.67 \mathrm{E}-11$ & $\mathrm{p}<0.001$ & Decrease \\
\hline Recovery & 48.576 & 11.202 & 2.04 & $1.70 \mathrm{E}-07$ & $\mathrm{p}<0.001$ & Decrease \\
\hline \multicolumn{7}{|c|}{ Spermatogonia cell area $\left(\mathrm{um}^{2}\right)$} \\
\hline Control & 76.407 & 17.017 & 3.403 & & & \\
\hline Experim. & 26.617 & 4.65 & 0.93 & $1.05 \mathrm{E}-18$ & $\mathrm{p}<0.001$ & Decrease \\
\hline Recovery & 32.926 & 7.464 & 1.627 & $1.16 \mathrm{E}-15$ & $\mathrm{p}<0.001$ & Decrease \\
\hline \multicolumn{7}{|c|}{ Primary spermatocyte cell area $\left(\mathbf{u m}^{2}\right)$} \\
\hline Control & 143.73 & 27.619 & 5.524 & & & \\
\hline Experim. & 29.302 & 7.728 & 1.546 & $7.06 \mathrm{E}-25$ & $\mathrm{p}<0.001$ & Decrease \\
\hline Recovery & 68.828 & 9.776 & 13.023 & $4.57 \mathrm{E}-17$ & $\mathrm{p}<0.001$ & Decrease \\
\hline \multicolumn{7}{|c|}{ PAS materials area percent $(\%)$} \\
\hline Control & 13.023 & 1.956 & 0.437 & & & \\
\hline Experim. & 8.537 & 1.705 & 0.381 & $2.56 \mathrm{E}-09$ & $\mathrm{p}<0.001$ & Decrease \\
\hline Recovery & 4.97 & 1.179 & 0.264 & $2.90 \mathrm{E}-18$ & $\mathrm{p}<0.001$ & Decrease \\
\hline \multicolumn{7}{|c|}{ DNA affinity (O.D.) } \\
\hline Control & 0.285 & 0.057 & 0.013 & & & \\
\hline Experim. & 0.424 & 0.082 & 0.018 & $2.66 \mathrm{E}-07$ & $\mathrm{p}<0.001$ & Increase \\
\hline Recovery & 0.377 & 0.074 & 0.016 & $8.40 \mathrm{E}-05$ & $\mathrm{p}<0.001$ & Increase \\
\hline
\end{tabular}

N.B. 1-Number of readings was 20 fields per rabbit (total 360 readings)

2- $\mathrm{SD}=$ Standard deviation $\quad \mathrm{SEM}=$ Standard error of mean $\quad \mathrm{t}$-Test $=$ Student's $\mathrm{T}$ test

3- O.D.=Optical Density 4- Statistical comparison was done vs control group data

p-value $=$ Probability

$5-\mathrm{p}<0.05$ was considered as statistically significance 
Figure-1 Effect of gossypol oral intake on the seminiferous tubules thickness in the different study groups

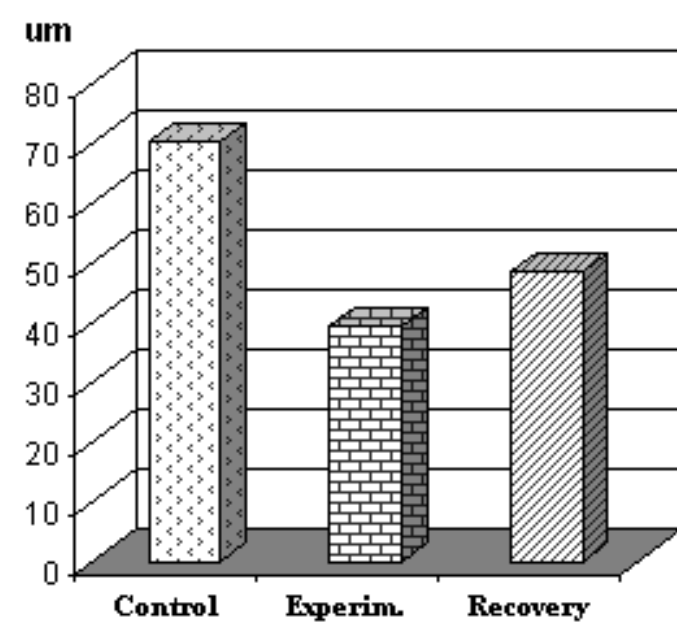

Figure-3 Effect of gossypol oral intake on the PAS positive area percent in the different study groups

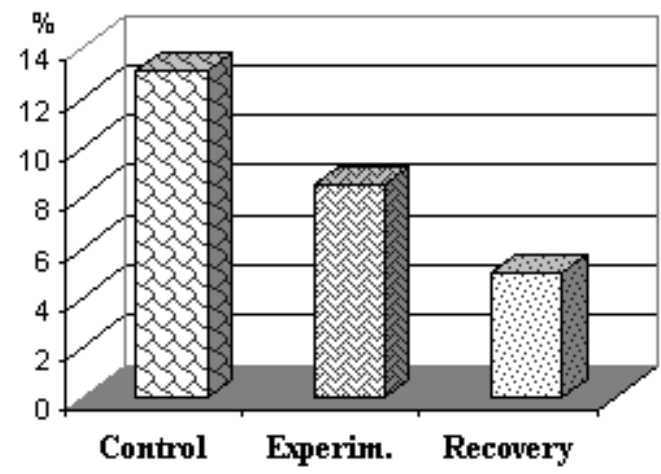

Figure-2 Effect of gossypol oral intake on the spermatogonia and primary spermatocytes cells areas in the different study groups

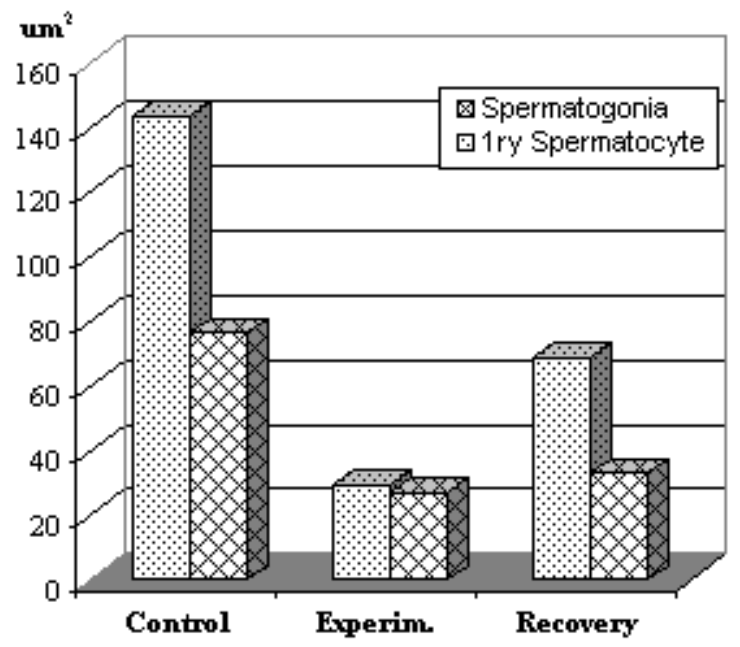

Figure-4 Effect of gossypol oral intake on the spermatogonia DNA optical density in the different study groups

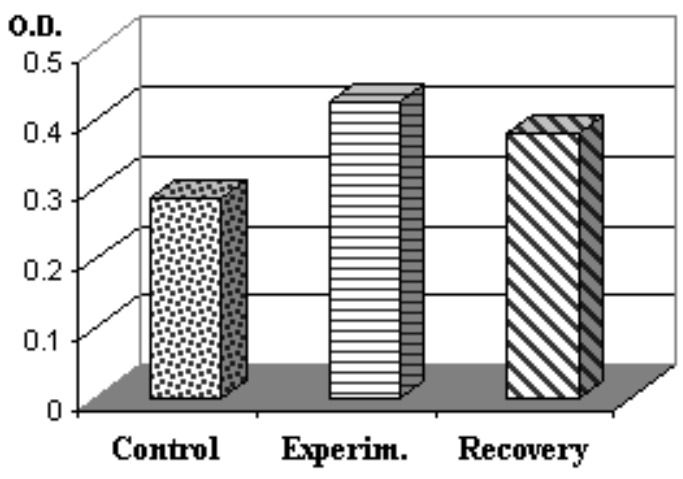




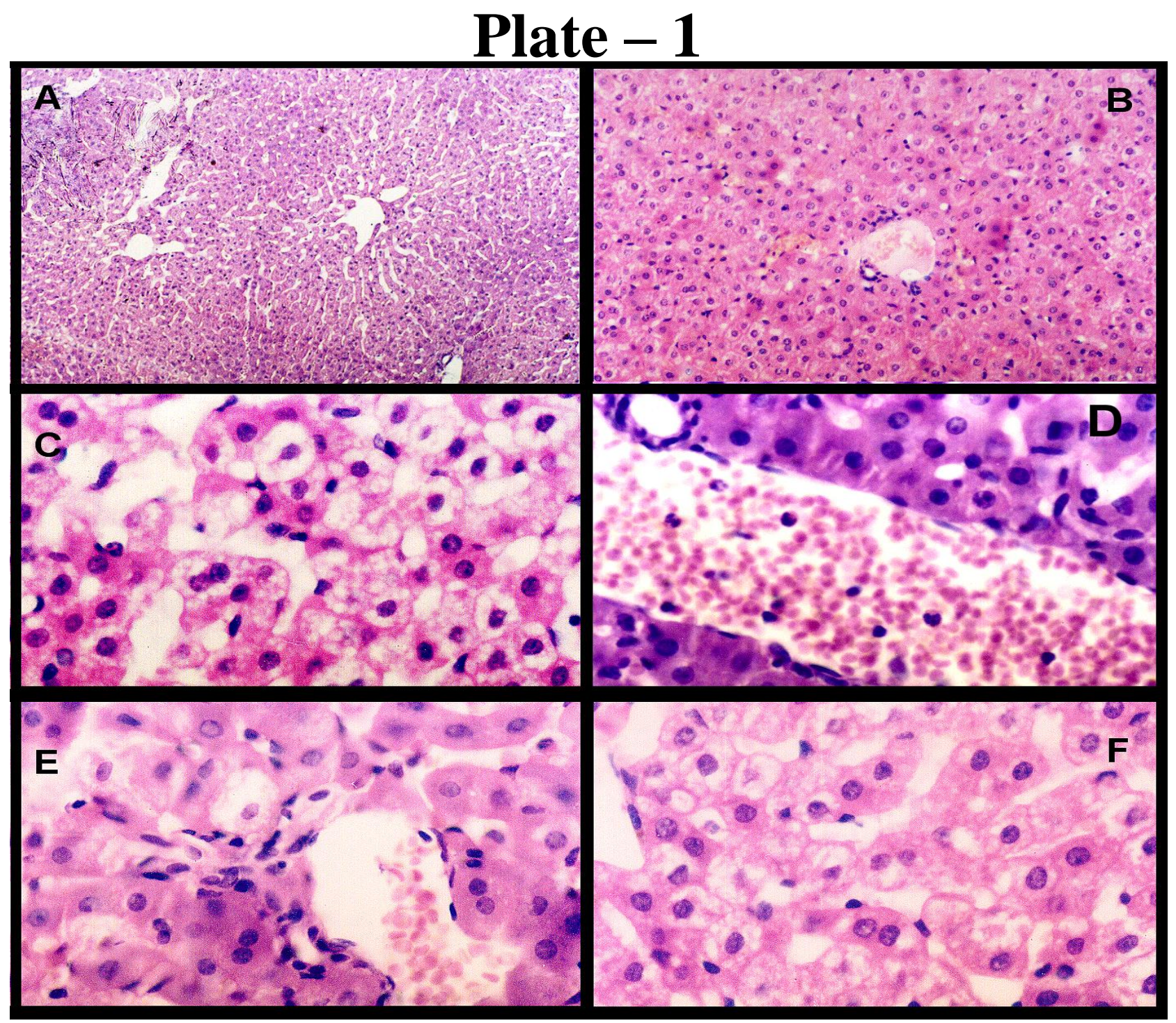

1-A A computerized photomicrograph of a section in the liver of control rabbit, showing the normal pattern of hepatic. (Hx and E. stain, X100)

1-B A computerized photomicrograph of a section in the liver of experimental group rabbit, showing pinpoints foci of hepatocytes with dark acidophilic cytoplasm and dark condensed nuclei (degenerative changes). (Hx and E. stain, X100)

1-C A computerized photomicrograph of a section in the liver of experimental group rabbit, showing hepatocytes with marked intracellular vacuoles and some hepatocytes with coagulative necrosis. (Hx and E. stain, X630)

1-D A computerized photomicrograph of a section in the liver of experimental group rabbit, showing dilated blood vessels with perivascular lymphatic aggregations and intravascular leucocytes populations. (Hx and E. stain, X630)

1-E A computerized photomicrograph of a section in the liver of experimental group rabbit, showing dilated blood vessels with perivascular lymphatic aggregations and intravascular leucocytes populations. (Hx and E. stain, X630)

1-F A computerized photomicrograph of a section in the liver of recovery group rabbit, showing hepatocytes with marked intracellular vacuoles and some hepatocytes with coagulative necrosis. (Hx and E. stain, X630) 


\section{Plate - 2}

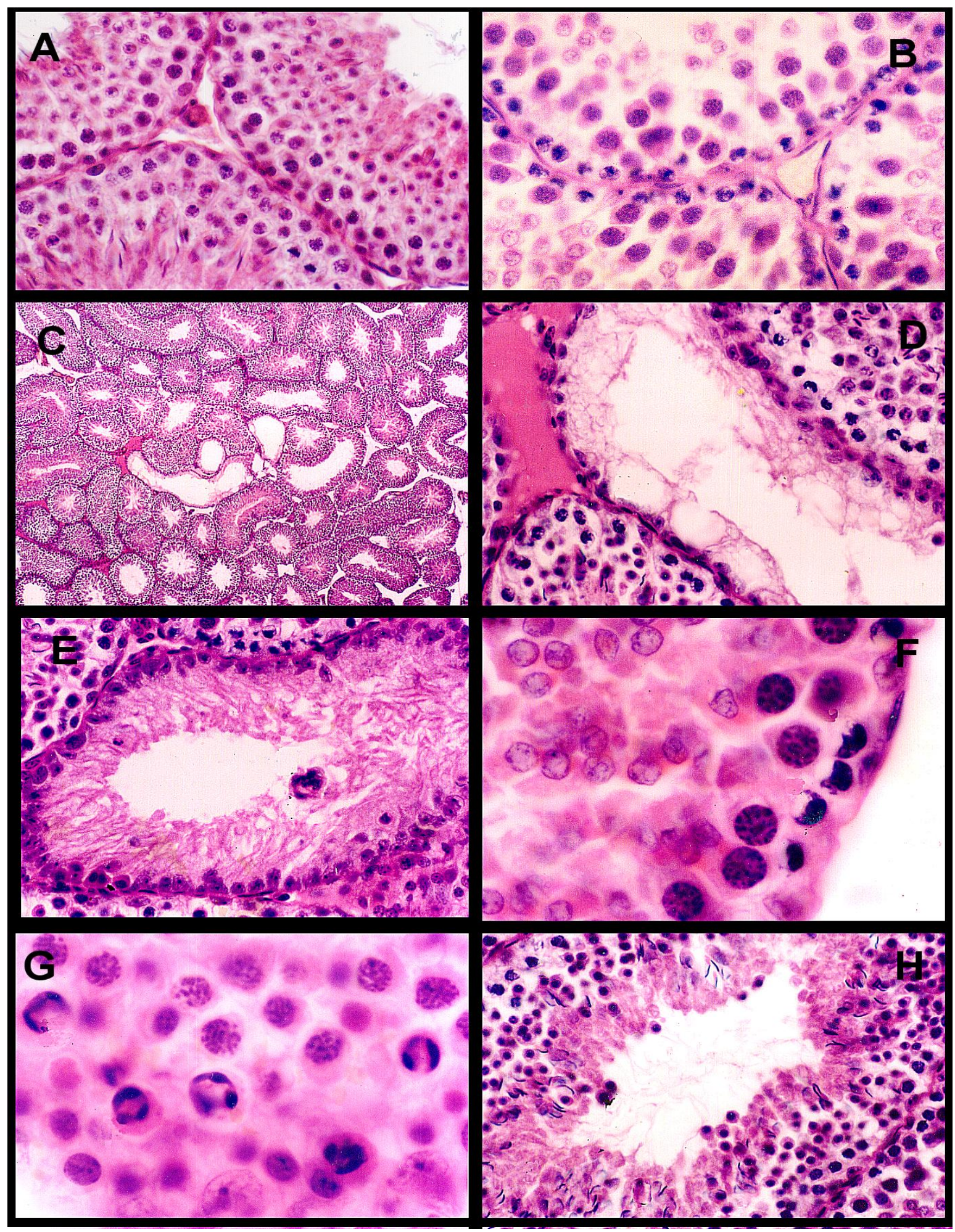


2-A A computerized photomicrograph of section in the testis of control rabbit, showing the normal pattern of seminiferous tubules and normal organization of germ cells- Sertoli cells adhesions. (Hx and E. stain, X400)

2-B A computerized photomicrograph of section in the testis of experimental group rabbit, showing seminiferous tubules with disturbed organization of germ cells- Sertoli cells adhesions and dislodged spermatogenic cells. (Hx and E. stain, X400)

2-C A computerized photomicrograph of section in the testis of experimental group rabbit, showing presence of some degenerated seminiferous tubules. (Hx and E. stain, X40)

2-D A computerized photomicrograph of section in the testis of experimental group rabbit, showing seminiferous tubules formed of one row of spermatogenic cells and Sertoli cells with vacuolated cytoplasm. (Hx and E. stain, X400)

2-E A computerized photomicrograph of section in the testis of experimental group rabbit, showing seminiferous tubules formed of one row of spermatogenic cells and degenerated spermatogenic cells and the presence of multinucleated giant cell intraluminal. (Hx and $\mathrm{E}$. stain, X400)

2-F A computerized photomicrograph of section in the testis of experimental group rabbit, showing different spermatogenic cells degenerated and the presence of prominent cellular internucleosomal DNA fragmentations in the spermatogonia cells. (Hx and E. stain, X1000)

2-G A computerized photomicrograph of section in the testis of experimental group rabbit, showing different spermatogenic cells and the presence of interstitial leucocytes populations. (Hx and E. stain, X1000).

2-H A computerized photomicrograph of section in the testis of recovery group rabbit, showing seminiferous tubules with intraluminal residual bodies. (Hx and E. stain, X400) 


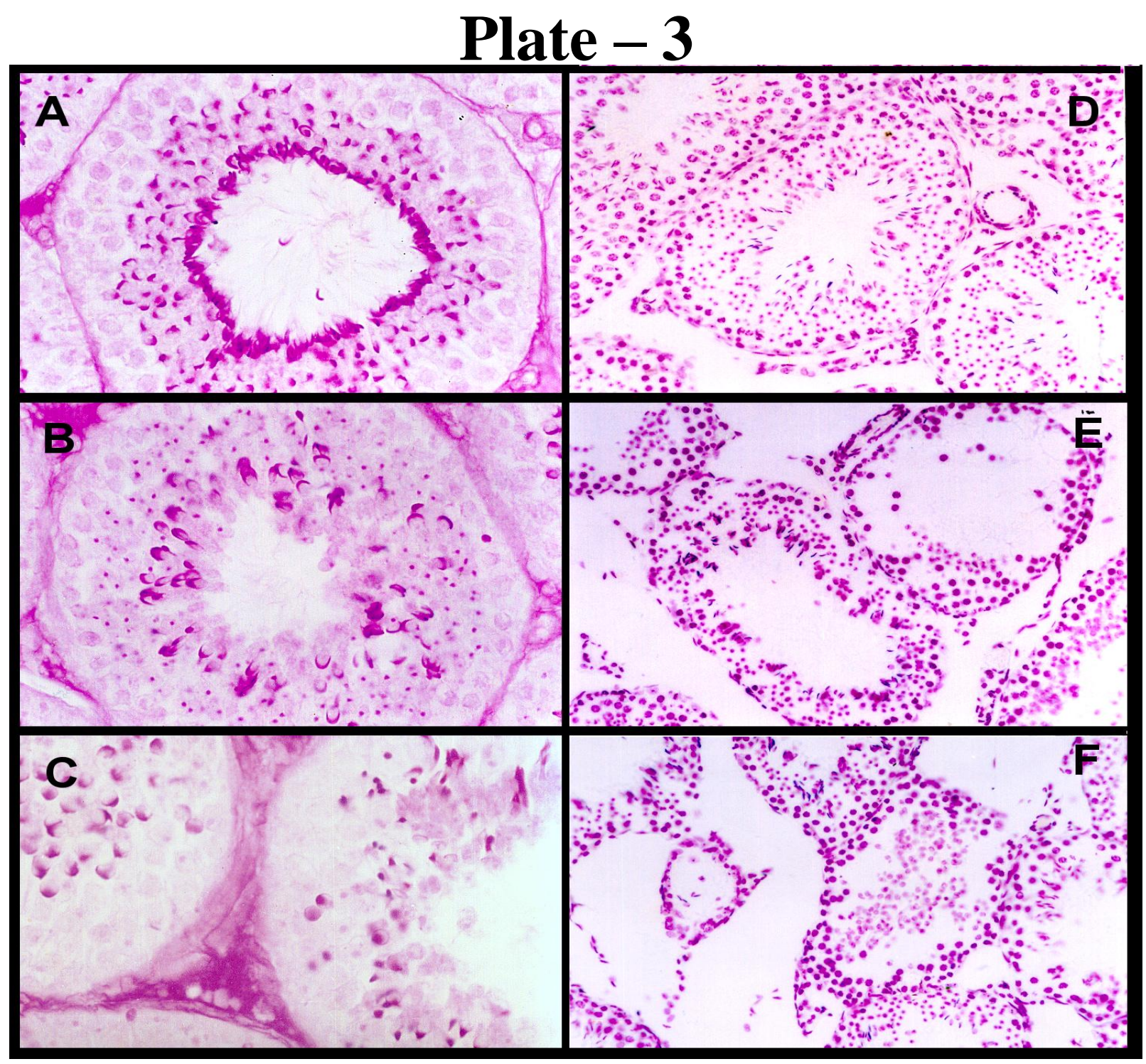

3-A A computerized photomicrograph of section in the testis of control rabbit, showing the normal distribution of PAS positive materials inside the seminiferous tubules and is more prominent in the head of sperms (PAS technique, X400).

3-B A computerized photomicrograph of section in the testis of experimental group rabbit, showing decrease of PAS positive materials contents inside the seminiferous tubules (PAS technique, X400)

3-C A computerized photomicrograph of section in the testis of recovery group rabbit, showing weak PAS positive materials concentrations inside the seminiferous tubules. (PAS technique, X400)

3-D A computerized photomicrograph of section in the testis of control group rabbit, showing DNA nucleic acid contents inside the different spermatogenic cells. (Feulgen Technique, X200)

3-E A computerized photomicrograph of section in the testis of experimental group rabbit, showing an increase DNA nucleic acid affinity to stain inside the different spermatogenic cells in comparison to control. (Feulgen Technique, X200).

3-F A computerized photomicrograph of section in the testis of recovery group rabbit, showing an increase DNA nucleic acid affinity similar to experimental cells. (Feulgen Technique, X200) 


\section{Discussion}

Gossypol, a constituent of cottonseeds, displays various drug properties, including male antifertility and anticancer. Toxicity is shown against the reproductive system, heart, and liver.

In this study we try to evaluate the effect of Gossypol on the liver and testis.

The present study revealed pinpoints degenerative necrosis in hepatocytes with perivascular capillary lymphocytic aggregations under the effect of oral contraceptive therapeutic dose of gossypol for 9 weeks. Also there was a failure to return to pre-treatment state.

Wang Y, and Lei HP (1987) studied the effect of gossypol acetic acid feeding to rats caused an increase in the SGPT level, decrease the liver concentration of cytochrome P-450 and induced marked pathological changes of liver cells in the form of vacuolization of mitochondria, dilation of endoplasmic reticulum and widening of perinuclear space as well as proliferation of collagen fibers in Disse's spaces. They stated that gossypol could bind to microsomal protein irreversibly either in the presence or absence of NADPH and concluded that gossypol acetic acid is capable of causing damage to liver cells.

Zelski RZ, et al., (1995) evaluated the liver of gossypol-treated rats which showed periacinar necrosis in acute cases and periacinar fibrosis in chronic cases

Similar pathological findings was observed by Deoras et al (1997), they reported that gossypol is a strong hepatotoxic agent which can produce severe hepatic damage in the form of biliary hyperplasia, periportal iron pigments deposition in the liver of lambs. They stated that the highest gossypol concentrations were found in the liver, the heart and testis and at necropsy. The livers of the treated rats appeared generally pale with distinct pinpoint foci of coagulative necrosis.

Histopathological studies done on gossypoltreated rats by Akingbemi et al. (1996) found, vacuolar degeneration of hepatocytes and dilation of the sinusoids in the liver, atrophy and leucocytes infiltration of cardiac myofibres, vacuolation of the renal glomerulus and cellular depletion of the spleen and thymus, and ethanol consumption had the effect of reducing gossypol toxicity, probably by reducing the amount of gossypol available for tissue exposure through enhanced metabolism and/or clearance from the body.

Histological and histochemical studies on the testis of rabbits in the current study showed distortion of spermatogenic cells and degenerated in some seminiferous tubules. Also there was disturbance of germ cells Sertoli cell organization. Histopathological changes were observed, as an intracellular vacuolization of Sertoli cells, presence of luminal multinucleated giant cells and a prominent cellular internucleosomal DNA fragmentation was observed in the spermatogenic cells.

Yan Cheng and Dolores D. (2002): reported that Gossypol and lonidamine are two compounds known to induce germ cell loss from the seminiferous epithelium when administered in vivo

Fiorini et al (2003), stated that, In the testis, Sertoli cells establish intercellular junctions that are essential for spermatogenesis. Sertoli cells expressed typical components of tight (occludin and zonula occludens-1), anchoring (N-cadherin) and gap (connexin 43) junctions. Testicular toxicants (DDT, pentachlorophenol, dieldrin, dinitrobenzene, cadmium chloride, cisplatin, gossypol, bisphenol A and tert-octylphenol) affected intercellular junctions by either reducing the amount or inducing aberrant intracellular localization of these membranous proteins.

In against to present findings, Hassan et al (2003) reported that in gossypol-treated bulls, there was no significant effect on the sperm motility, scrotal circumference, or Histopathological characteristics of the testes. 


\section{Quantitative microscopical and histochemical changes}

The deleterious effects of gossypol on the morphological characteristics of spermatozoa were reversible. Gossypol $(8 \mathrm{mg} / \mathrm{kg}$ per day for 56 days) increased sperm abnormalities but the effects were reversible.

Cerelli JS, and Johnson L. (1999); they concluded that the bull did experience significant degeneration of germ cells between B spermatogonia and pachytene primary spermatocytes, with no subsequent loss throughout the rest of spermatogenesis, and the gossypol-enriched diet did not further enhance germ cell degeneration.

Monsees TK et al., (1998) reported that Gossypol was found to induce DNA strand breaks in rat lymphocytes. Examination of cell morphology and DNA fragmentation at incubations up to $5 \mathrm{~h}$ yielded no evidence that DNA strand breaks were occurring due to apoptosis. They concluded that gossypol is not primarily genotoxic in this cell type, and that the DNA breaks observed are secondary to cytotoxicity.

Waites et al (1998), stated that the cessation of clinical studies on gossypol because of increased risk in irreversible testicular damage and low therapeutic ratio is recommended. Their recommendations depended upon the studies that conducted in China confirm the efficacy of gossypol as a male antifertility drug. That paper presents the extensive investigations on formal animal toxicology and on the recovery of male fertility after cessation of gossypol use. Studies conducted by the International Organization for Chemical Sciences in Development showed that 40 of the 70 highly purified, novel structural forms of gossypol were no more active than gossypol. Experiments conducted on Sprague-Dawley rats and cynomolgous monkeys confirm that gossypol is too toxic to be developed for human contraception. Among the side effects associated with the use of gossypol, the most serious was hypokalemic paralysis. On the other hand, studies that examine the risk of permanent sterility among healthy reproductive males were confirmed by two separate studies, which found an incidence of
$25 \%$ irreversible sterility. The failure of recovery among those who stopped gossypol use could be attributed to longer treatment, greater total dose of gossypol, smaller testicular volume, and elevated follicle stimulating hormone concentrations.

Zhuang et al., (1983); evaluated the direct effect of gossypol on testicular cells, by using primary cultures of rat Leydig and Sertoli cells. No alteration in Leydig cell survival, morphology, or testosterone production was seen during three days of culture with up to 3 microgram $/ \mathrm{ml}$ gossypol. With higher concentrations (3 to 7 microgram $/ \mathrm{ml}$ ) of gossypol, there was a reduction in cell survival but no change in androgen secretion. In contrast, there was a marked change in Sertoli cell morphology after five days of gossypol treatment. Large vacuoles and electron dense granules appeared in the cytoplasm, but these effects were reversed within six days of removing gossypol from the medium. There was a significant decrease in androgen binding protein (ABP) secretion by Sertoli cells in the presence of gossypol. These results suggest that, of the somatic cell types in the testis, the Sertoli cells are most sensitive to gossypol.

Tung et al (1987); made a study done on 16 male volunteers, ages $30-45$ years, were treated with gossypol $40 \mathrm{mg}$ per week for 6-8 years. Their wives never became pregnant during the treatment period. Gossypol suppressed spermatogenesis, prevented sperm maturation, and inhibited sperm motility. In 1 case out of 5 tested, the testis completely lacked germ cells, some spermatocytes remained in 3 , and 1 still had all types of germ cell intact although the number was reduced from that found in normal seminiferous tubules. These tubules we severely degenerated and their volume decreased to less than $1 / 2$ of what is considered normal. The basic lamina of the tubules thickened and protruded into the epithelium. Sertoli cells were highly vasculolized, degenerated, and exfoliated into lumen. In some cases, the tubules became fibrotic. In the cytoplasm of the Sertoli cells, 
there were vacuoles of different sizes which were surrounded by or fused with lysosomes. Leydig cells changed in both number and size. It would appear that gossypol acts prior to or in conjunction with the incorporation of selenium into mitochondrial selenoprotein and that longterm treatment with gossypol affects not only the germ cells but the Sertoli and Leydig cells as well.

Hoffer AP (1983); studied the effects of 10,20 and $30 \mathrm{mg} / \mathrm{kg}$ per day of gossypol for 2-11 weeks on the rat testis. At the light microscope level, there were severely damaged and entirely normal seminiferous tubules adjacent to one another in the same section. Affected tubules exhibited intraepithelial vacuoles of varying size, exfoliation, and atrophy. With the electron microscope, the intraepithelial vacuoles were found to consist of intercellular spaces and intracellular vacuoles occurring primarily, though not exclusively, in the Sertoli cells. Severely affected Sertoli cells exhibited many large vacuoles as well as an overall decrease in cytoplasmic ground substance, rough and smooth endoplasmic reticulum and Golgi apparatus. There was an overall increase in the frequency of occurrences of vacuolated tubules with time and dose but in no group of animals were more than $46 \%$ of the tubules affected. At the electron microscope level, there was production of ultrastructural defects exclusively in the mitochondrial sheath of Stage 18 and 19 spermatids; these changes were evident in small numbers as early as 2 weeks after $20 \mathrm{mg} / \mathrm{kg}$ per day of gossypol and increased with dose and time.

The study concluded that gossypol has a toxic effect on the liver and testis of rabbits and their toxicity may be more prominent in humans. The study recommend restriction of uses of cotton seed oil in human uses and further study on the possible risk of uses of cattle fed on cottonseed meals.

\section{References}

1. Akingbemi BT, Rao PV, and Aire TA (1996): Ethanol intake may modify gossypol toxicosis in the rat. J Appl Toxicol. 1996 Sep-Oct;16(5):375-80

2. Cerelli JS, and Johnson L. (1999): Potential daily sperm production, Sertoli cell number, and seminiferous tubule characteristics in beef bulls fed conventional or gossypol-enriched diets. J Androl. JulAug; 20 (4):519-28

3. Deoras DP, Young-Curtis P, Dalvi RR, and Tippett FE (1997): Effect of gossypol on hepatic and serum gamma-glutamyltransferase activity in rats. Vet Res Commun. Jul;21(5):317-23.

4. Drury R. A. and Wallington J, (1996)" Carleton's histological techniques. $5^{\text {th }}$ ed. Oxford Univ. Press.

5. Fiorini C, Tilloy-Ellul A, Chevalier $\mathbf{S}$, Charuel C, Pointis G.(2003): Sertoli cell junctional proteins as early targets for different classes of reproductive toxicants. Reprod Toxicol. May ;18(3):413-21.

6. Hassan ME, Smith GW, Ott RS, Faulkner DB, Firkins LD, Ehrhart EJ, and Schaeffer DJ. (2003): Reversibility of the reproductive toxicity of gossypol in peripubertal bulls. Theriogenology. Apr 15; 61(6):1171-9.

7. Int J Toxicol. (2001): Final report on the safety assessment of Hydrogenated Cottonseed Oil, Cottonseed (Gossypium) Oil, Cottonseed Acid, Cottonseed Glyceride, and Hydrogenated Cottonseed Glyceride. Int J Toxicol. 2001; 20 Suppl 2:21-9. [No authors listed]

8. Meng GD, Zhu JC, Chen ZW, Wong LT, Zhang GY, Hu YZ, Ding JH, Wang XH, Qian SZ, and Wang C, et al. (1988): Follow-up of men in the recovery period immediately after the cessation of gossypol treatment. Contraception. 1988 Feb;37(2): $119-28$

9. Monsees TK, Winterstein U, Schill WB, Miska W (1998): Influence of gossypol on the secretory function of cultured rat sertoli cells. Toxicon. May;36(5):813-6.

10. Morris ID (1986): Gossypol: a male contraceptive with potential?. IRCS J Med Sci. 1986 Dec;14(12):1177-80.

11. Qian, S.Z. and Wang, Z.G. (1984): Gossypol, A potential antifertility agent for males, Ann. Rev. Pharmacol. Toxicol., 24:329-360.

12. Tung DS, Zhang GH, Xiang SC, Zhang GY, and Tsong SD (1987): Effect of long 
term gossypol treatment on human testicular structure. Adv Contracept Deliv Syst. Feb;3(1):47-50.

13. Waites GM., (1993): Male fertility regulation: the challenges for the year 2000 . Br Med Bull. Jan;49(1):210-21.

14. Waites GM, Wang C, Griffin PD.(1998): Gossypol: reasons for its failure to be accepted as a safe, reversible male antifertility drug. Int $\mathrm{J}$ Androl. Oct;2 1(5):313.

15. Wang Y, and Lei HP (1987): Hepatotoxicity of gossypol in rats. J Ethnopharmacol. Jun;20(1):53-64
16. Yan Cheng and Dolores D. Mruk (2002): Cell Junction Dynamics in the Testis: Sertoli-Germ Cell Interactions and Male Contraceptive Development. Physiol. Rev. 82: $825-874$

17. Zelski RZ, Rothwell JT, Moore RE, and Kennedy DJ (1995): Gossypol toxicity in preruminant calves. Aust Vet J. 1995 Oct;72(10):394-8

18. Zhuang LZ, Phillips DM, Gunsalus GL, Bardin CW, and Mather JP (1983): Effects of gossypol on rat Sertoli and Leydig cells in primary culture and established cell lines. J Androl. Sep-Oct;4(5):336-44. 


\section{التغيرات المجهرية والهيستوكيميائية الكمية علي كبد وخصية الأرانب البالغة

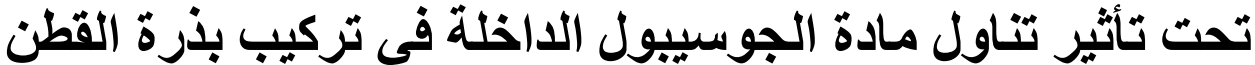

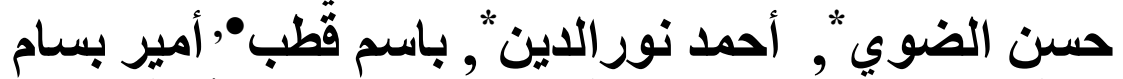

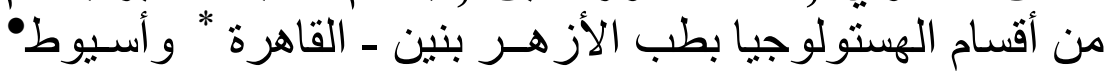

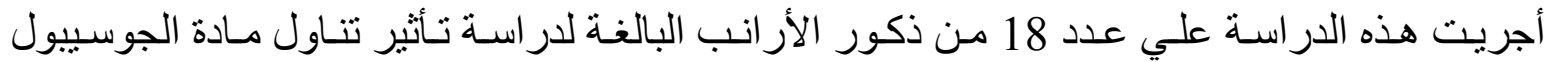

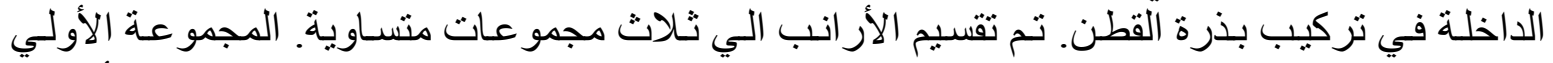

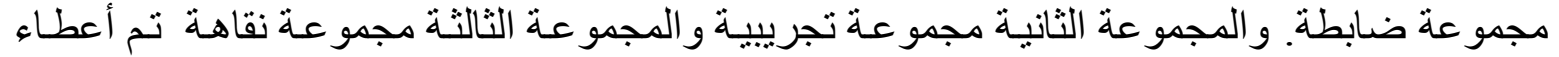

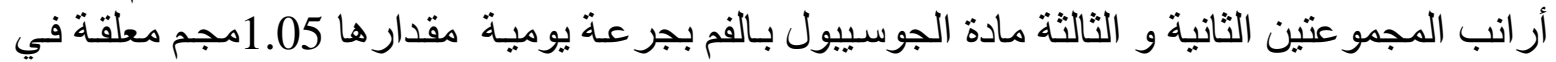
1مليلتر من زيت الزيتون النقي لمدة 9 أسابيع متصلة. وتم ترك أر انب المجمو عة الثالثة لمدة 9 أسابيع أخري لدر اسنة فترة النقاهة.

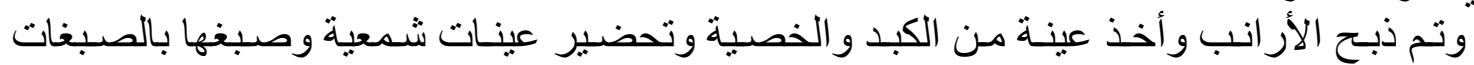

الهيستولوجية المناسبة وفحصها بجهاز تحليل الصور بالكمبيوتز وتحليل النتائج أحصائيا.

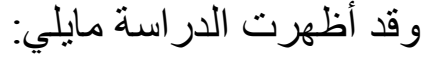

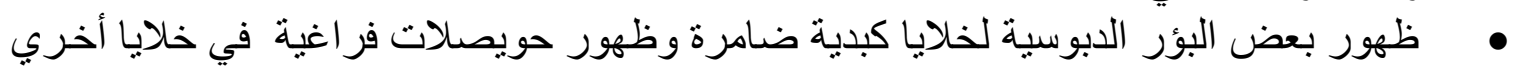

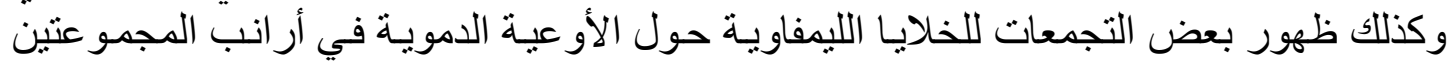

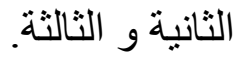

ضـمور ونقص في الخلايـا النطفيـة للحيو انـات المنويـة مـع ظهور أختلال في تنسيق الخلايـا

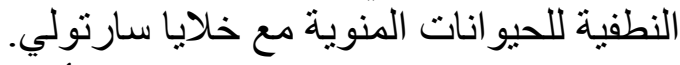
ظهور بعض الخلايا العملاقة متعددة الأنوية بتجويف لنيف الأنابيب البرزية.

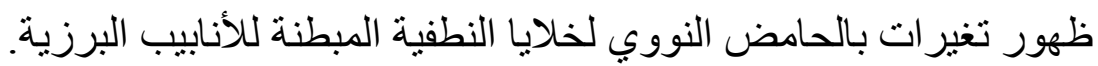
ظهور نقص ذو دلالة أحصائية في سمك الخلايـا النطفية المبطنة للأنابيب البرزية النية, مساحات بعض الخلايا النطفية.

• ظهور نقص ذو دلالة أحصائية في نسبة المساحات القابلة لصبغة الثبيف للانابيب البرزية.

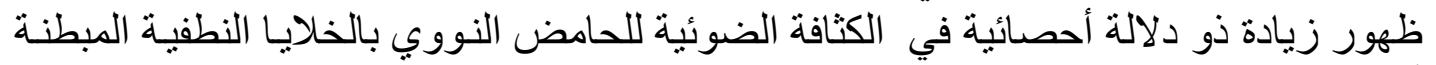

$$
\text { لكأنابيب البرزية. }
$$

عدم رجوع التغيير ات المجهرية الى طبيعتها بعد توقف تناول مادة الجوسيبول التيول لمدة 9 أسابيع.

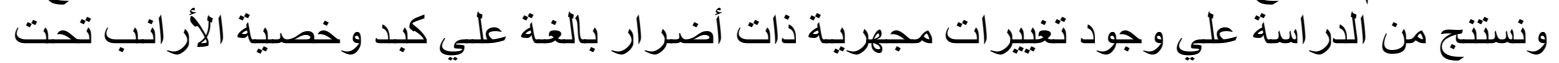

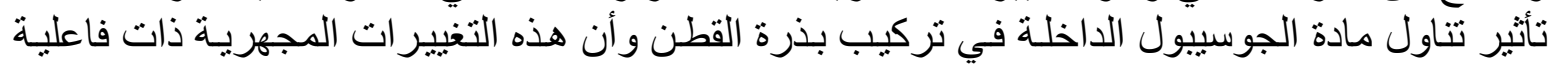
أكبر علي الأنسان. وتتصح ألدر استة علي تجنب تلتـاول زيت بذرة القطن بكثرة للأستخدام الادمي و أجر اء در اسـات علي تأثثير تتاول اللحوم التي تتغذي علي بذرة القطن علي صحة الأنسان. 